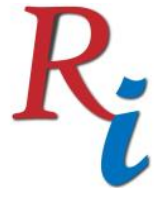

Asia Proceedings of Social Sciences

(APSS)

www.readersinsight.net/APSS

\title{
ETHNOPRAGMATIC STUDY ON JAVANESE NONVERBAL \\ LANGUAGE \\ Pranowo*
}

Master Program of Indonesian Language and Literature

Universitas Sanata Dharma Yogyakarta

Indonesia

*Corresponding author's Email: prof.pranowo2@gmail.com

Author's Biography

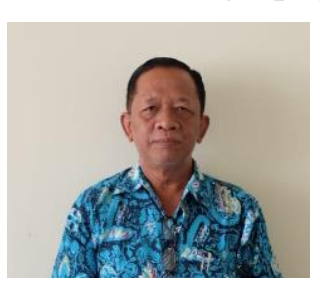

Prof. Dr. Pranowo, M.Pd., was born in Klaten, Central Java, Indonesia, on December 25, 1954. Hhe serves as a senior lecturer at the Master Program in Indonesian Language and Literature Education, Sanata Dharma University, Yogyakarta. He graduated from the Doctorate Program of Malang State University, in the field of language teaching and education in 1998.

Peer-review under responsibility of $3^{\text {rd }}$ Asia International Multidisciplanry Conference 2019 editorial board (http://www.utm.my/asia/our-team/) (C) 2019 Published by Readers Insight Publisher, lat 306 Savoy Residencia, Block 3 F11/1,44000 Islamabad. Pakistan, info@ readersinsight.net This is an open access article under the CC BY-NC-ND license (http://creativecommons.org/licenses/by-nc-nd/4.0/). 


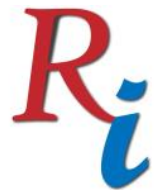

\section{Asia Proceedings of Social Sciences \\ (APSS) \\ www.readersinsight.net/APSS}

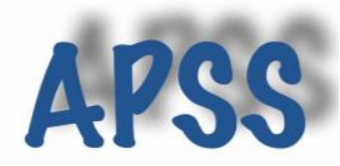

\section{Rese a r ch H i g h I ght s}

This etnopragmatic research can be highlighted below. (A) There are three types of nonverbal language: the one that can stand on its own, the one that becomes the context of spoken verbal language, and the one whose metaphorical form represents one's social status in the community. (B) Nonverbal language that can stand on its own is used when someone communicates without using words, but using gestures, sign language, sings, symbols, movements, eye gaze, hand shake, and noddin, etc (Polly E. Szatrowski, 2014). In such forms, nonverbal language is the basic means of communication among children who cannot speak verbal language or for two people who cannot speak each other's verbal languages. (C) The forms of dynamic nonverbal language are: (1) movement of the head and its parts (such as lip movement, eye movement), (2) movement of the hand and its parts, (3) movement of the body and its parts (such as belly movement, movement of body parts, movement of chest, and movement of the buttocks). The forms of static nonverbal language are (1) body posture, facial features, hair color, skin tone, cheek shape, etc. (D) The functions of dynamic and static nonverbal language are: (1) to eliminate meaning obscurity in the speaker's intent, (2) to clarify understanding of the speaker's utterance containing implicature, (3) to bec the reference of utterances containing deixis, and (4) to clarify social status, level of ntellectual ability, and one's social ranks.

\section{Research Objectives}

The purpose of this study is to describe the Javanese people's perspective on the use of nonverbal language, both dynamic and static. In general, nonverbal language provides contexts for the spoken verbal language. However, in practice, nonverbal language can stand on its own, provide contexts for spoken nonverbal language, and metaphorically act as the symbol of one's social status in the society. The scope of the enthnographic study covers cultural knowledge, cultural behavior, and artifacts (Saroh et al., 2018); . Thus, the use of nonverbal language is a cultural behavior, which means that each nonverbal language reflects the cultural behavior of the given speech community. The scope of the pragmatic study is the study of language use, both in the aspect of understanding the language and expressing the language based on contexts. Therefore, the ethnographic study is a study of language use focusing on the aspect of understanding and expressing the language based on the context of cultural behavior of a given society (Kirmayer, 2015).

\section{Methodology}

This research is a descriptive qualitative study focusing on the Javanese as the research subject. The research data is in the form of spoken verbal utterances containing nonverbal language. The data was collected using observation techniques, interviews, and recording (Mahsun, 2005). The researcher observed the Javanese people speaking Javanese as the first language and Indonesian as the second language. The researcher also conducted interviews with several informants to confirm the messages delivered using nonverbal language. To support data collection, the researcher also uses audiovisual recording to corroborate the observation results. Since the researcher is of the Javanese, the research instrument is the researcher himself with an understanding of the Javanese language and culture (Anderson, 1972). The collected data is then analyzed in the following steps: (1) identifying data, (2) classifying data, and (3) interpreting messages contained in the research data. 


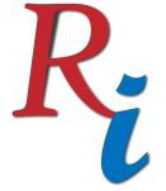

Asia Proceedings of Social Sciences

(APSS)

www.readersinsight.net/APSS

\section{Results and Findings}

The data analysis result of the dynamic and static nonverbal language included (a) head movements (such as nodding, shaking, lip movement, squinting), (b) body movements (such as hand movement, finger movement, leg movement, hip movement, and buttocks movement), (c) symbolic metaphorical (such as rank, social status, and wealth, etc.), (d) skin colors, nose shapes, body posture, and hair colors. The analysis results of both dynamic and static nonverbal language functions (Ephratt, 2011) show that nonverbal language functions are able to (a) eliminate the vagueness of the speaker's meaning, (b) clarify the hearers' understanding of the utterances containing implicature, and (c) become the reference of the utterances containing deixis.

\section{References}

Anderson, B., 1972. The Idea of Power in Javanese Culture. Cult. Polit. Indones. https://doi.org/10.1017/CBO9781107415324.004

Ephratt, M., 2011. Linguistic, paralinguistic and extralinguistic speech and silence. J. Pragmat. https://doi.org/10.1016/j.pragma.2011.03.006

Kirmayer, L.J., 2015. Mindfulness in cultural context. Transcult. Psychiatry. https://doi.org/10.1177/1363461515598949

Mahsun, M., 2005. Metode Penelitian Bahasa. Jakarta PT Raja Grafindo Persada. https://doi.org/10.1200/JCO.2008.17.1991

Polly E. Szatrowski, 2014. Language and Food Verbal and nonverbal experiences, 1st ed. John Benjamin Publishing Company, Amsterdam.

Saroh, U., Kristanto, M., Khasanah, I., 2018. INTERAKSI SOSIAL ANAK DALAM PERMAINAN CUBLAKCUBLA SUWENG PADA USIA 2-4 TAHUN DI TPA PENA PRIMA TAHUN 2017. PAUDIA J. Penelit. DALAM Bid. Pendidik. ANAK USIA DINI. https://doi.org/10.26877/paudia.v6i2.2107 